Insight

\title{
Sustainable Biomass Energy and Indigenous Cultural Models of Well- being in an Alaska Forest Ecosystem
}

\author{
Munish Sikka $^{1}$, Thomas F. Thornton ${ }^{2}$ and Rosita Worl ${ }^{3}$
}

\begin{abstract}
Oil-dependent indigenous communities in remote regions of Alaska and elsewhere are facing an unprecedented crisis. With the cost of fuel and transport skyrocketing, energy costs are crippling local economies, leading to increasing outmigration and concern for their very existence in the future. What can be done to address this energy crisis, and promote energy security, sustainability and resilience in rural forest communities? We examine the potential of developing a sustainable biomass-energy industry in Southeast Alaska, home to nearly 16,000 Alaska Natives in a dozen rural and two urban communities within the United States' largest national forest: The Tongass. Although the potential for biomass energy has long been touted, realization of the opportunity has been catalyzed only recently as part of a model of sustainable development being enacted by the region's largest Native corporation, Sealaska, and its subsidiary, Haa Aaní ("Our Land") L.L.C. In this paper we examine the unique nature of Alaska Native corporations and their potential as engines of sustainable development, particularly through Sealaska's emerging cultural model of sustainability in relation to social-ecological well-being. We assess the economic, ecological, and atmospheric emissions parameters of a wood-biomass energy industry at various scales according to the "triple bottom line" of sustainability. Finally, we address what additional policy and support measures may be necessary to nurture the successful transition to biomass energy at a sustainable scale to support rural indigenous communities, a more resilient, renewable energy system, and a lower carbon footprint.
\end{abstract}

Key Words: forest ecosystems; indigenous communities; Native corporations; policy recommendations; sustainable development; triple bottom line analysis; wood-biomass energy

\section{INTRODUCTION}

Energy is the lifeblood of social-ecological systems. Without a local supply human communities must depend on distant energy production and distribution systems, which typically have significant externalities, vulnerabilities, and limits. With the global shift toward cheap fossil fuels in the 20th century, many remote communities, especially in the developed world, were able to support unprecedented development. However, this development created dependencies that are now crippling communities as prices soar and supplies dwindle. Yet studies of energy in these human and natural systems remain few (Nader 2010), and there is a need to go beyond the economic and technical problems of energy supply and better analyze its social and ecological dimensions.

Before petroleum, biomass energy, particularly wood, was the most important source of energy to humankind. It remains a critical energy source for at least two billion people (McQueen and Korhaliller 2011). Widespread use of biomass or biofuels has been a contentious issue in different parts of the world. There are inherent advantages of using bioenergy instead of fossil-fuels, the combustion of which results in large net $\mathrm{CO}_{2}$ emissions. Biomass is a renewable and potentially carbonneutral source of energy. Plants harvested sustainably for fuel can grow again thereby sequestering carbon from the atmosphere (Lippke et al. 2011). However, some studies suggest that the emissions associated with direct and indirect land-use change alone may negate the estimated climatic benefits of biofuels, particularly when they supplant carbonrich ecosystems and displace food production (German et al. 2011). Moreover, biofuel feedstock cultivation may have implications for rural livelihoods and traditional land rights that depend on existing biomass and associated ecosystem goods and services. Therefore, more case studies are needed to understand the complex social and environmental impacts accruing from the expansion of biomass energy.

Commercial interests, including multinational corporations, promoting fossil fuel and biofuel development often have pushed aside local indigenous peoples and ethnic minorities reliant on land resources but lacking tenure security (Survival International 2008, Natcher et al. 2009). However, what if the commercial interest is a rooted, indigenous corporation with its own forest capital? We evaluate the potential for biomass energy development using the case of Southeast Alaska, where Native corporations, led by the Sealaska Corporation with more than 279,000 acres of forest lands and 21,000 mainly Tlingit and Haida shareholders, are attempting to develop a sustainable biomass energy industry. We assess the sustainability of bioenergy development in two ways: first according to Sealaska's own values of sustainability, which it seeks to operationalize within a "triple bottom line" of economic, social, and environmental cobenefits with rural Southeast communities; and second, according five biomass

${ }^{1}$ Former Student at University of Oxford, ${ }^{2}$ Senior Research Fellow, Environmental Change Institute, University of Oxford, ${ }^{3}$ President - Sealaska Heritage Institute 
energy sustainability criteria (see Helle et al. 2009) applied to Southeast as a social-ecological system. The latter include: (1) greenhouse emission reductions to mitigate climate change; (2) compatibility with local food systems and land and resource use; (3) maintenance of ecosystem services and human well-being; (4) consideration for key cultural values; and (5) net economic benefits at the bioregional level.

Southeast Alaska is home to a dozen Tlingit and Haida communities, organized into matrilineal clans, tribes, and village and regional business corporations. Throughout the region, rural villages reliant on fossil fuels for electricity and heat face enormous energy challenges because of globally increasing oil prices. At the same time Native corporations are the largest private landholders and stakeholders in the region's forest industries. Tlingit and Haida communities and their corporations consider the Tongass National Forest, America's largest national forest and part of the largest temperate rain forest ecosystem in the world, their homeland, and rely on it for subsistence hunting, fishing, and gathering as well as wage livelihoods. The Tongass comprises some 17 million acres of which 3.4 million acres have been designated for timber development, though environmental protections and other restrictions have effectively reduced the available timber base to about 650,000 acres. Native corporations have developed a timber industry on these lands that has proven profitable but not sustainable. Could the utilization of biomass residue from Southeast Alaska's forest industry meet local energy requirements to improve the sustainability of rural communities and forest livelihoods while at the same time reducing climate impacts in the region?

\section{METHODS}

To address this question we employed a mix of qualitative and quantitative methods, based on a review of the biomass energy and policy literature, interviews with Native leaders, forest and energy experts, and a set of calculations to evaluate energy transition costs and climate benefits through reduced carbon emissions. The lead author, a forester by training, conducted two months of fieldwork at Sealaska Corporation and carried out most of the interviews. The second author has worked among the Tlingit and Haida on natural and cultural resource management issues, including timber, fish, and wildlife management, for over 20 years, while the third author is the president of the Sealaska Heritage Institute and a member of the corporation's Board of Directors, as well as a professional anthropologist. This combined expertise gave the team unique access to both inside and outside views of biomass fuels and their potential as a sustainable energy development strategy in the region.

In-depth interviews were conducted with 17 researchers and field staff associated with the U.S. Forest Service, Sealaska Corporation executives and shareholders, and representatives from nongovernmental organizations, including environmental groups, working on issues related to energy and conservation in Southeast Alaska. Quantitative methods were used to calculate the environmental benefits of using wood-pellets over oil, including emission quantities of various gases. The climate-energy formula developed for this study can be used to conservatively calculate emission reductions achieved by switching from oil to wood-pellets for heat or electricity in any forest setting.

\section{ALASKA NATIVE CORPORATIONS AND SUSTAINABLE DEVELOPMENT}

The Alaska Natives Claims Settlement Act (ANCSA) of 1971 established Native corporations as major vehicles for sustainable development in Alaska's biocultural regions of which Tlingit and Haida country is the southernmost. A hybrid of termination (1950-1960s) and self-determination (1970s-) strains of Federal Indian policy, the Act sought to reduce Native dependence on federal programs and thereby avoid social problems associated with Indian reservations in the Lower 48 states (Thornton 2002). At the same time, ANCSA was to provide a just settlement to longstanding claims to lands confiscated from Natives by the government and private entities. The settlement extinguished aboriginal land title but allowed for Natives to retain some 44 million acres of land (about 9\% of Alaska but, critically, less than 3\% of the Tongass Forest, because of restrictions placed on Native land selections by the U.S. Forest Service, beholden to powerful non-Native timber interests), and to receive compensation of $\$ 962.5$ million for lands taken (about $\$ 3$ per acre). The land and capital were divided among 12 regional and some 200 village and urban corporations, and approximately 80,000 Natives were enrolled as stockholders. ANCSA, along with the rapid development of the oil industry, have transformed Alaska's economy, while posing profound social and environmental challenges for Alaska Native communities (Berger 1985, Dombrowski 2002, Thornton 2007).

Significantly, only claims for uplands were compensated under ANCSA. State appropriations of marine territory and coastal and intertidal resources were not compensated, and, in contrast to Alaska's only (Tsimshian) Indian reservation at Annette Island, no marine waters were conveyed. For maritime peoples like the Tlingit and Haida, this necessitated a major reorientation from a coastal fishing economy to an upland timber management corporation, according to their revised stocks of natural capital. Lacking expertise in forest industries, many Native corporations hired outside consultants who advised them according to the prevailing forest management and timber economics paradigms of the day, which considered trees as a regenerative crop to be harvested according to maximum yield principles within the constraints of environmental regulation and market prices. As a result of this advice and a temporary corporate welfare scheme that allowed Native corporations to sell net operating losses (NOLS) from their timber operations to profitable non-Native corporations for tax relief, but only if they cut the trees, most Southeast 
Native corporations clear-cut their valuable old growth timber within their first generation of operation, drawing criticism from environmentalists and local shareholders whose subsistence activities were adversely impacted by intensive logging (Dombrowski 2002, Durbin 2005, Alexander et al. 2010; N. Soboleff, personal communication 2011).

These logging practices stressed forest ecosystems on Native lands, but even with a more conservative approach, it would have been impossible for most corporations to sustain profitable timber operations because of their circumscribed land base of 23,000 acres. Thus, most village corporations took their profits and losses with their first generation of operation, and then diversified into other businesses or investments. Only the regional corporation and largest landholder, Sealaska, maintained significant timber operations and these too have been scaled back.

A conservation ethos is not innate or inherent in society, but rather tends to develop when a resource is recognized as important, limiting, and depletable, and succeeds when resources are resilient and users have effective institutions and control in regulating them for present and future use (Smith and Wishnie 2000, Hunn et al. 2003, Berkes 2008, Ostrom 2009). Tlingits traditionally recognized trees as beings (Emmons and de Laguna 1991) and even carried out ceremonies before felling large trees for such things as canoe and clan house construction, these objects being conceptualized similarly as beings. A strong conservation ethos around tree harvest did not necessarily develop, although weavers intentionally did not gather all the roots of favored spruce trees to allow them to survive for future generations. Unlike salmon or other key resources (Thornton and Kitka 2010), the dominant forest species (Sitka Spruce, Picea sitchensis and Western Hemlock, Tsuga heterophylla) were not experienced as depletable. In the wake of first generation industrial logging experiences, however, Native corporations increasingly came to view local timber as a limited resource and large-scale clear-cutting as operationally unsustainable on their restricted and fragmented land base. As village corporations wound down timber operations, Sealaska Corporation's Board of Directors established a Land Committee to assess the future of its timber operations. The board elected to pursue land legislation that would allow Sealaska to select its remaining land entitlement in areas with second growth trees as a means to move toward sustainability of its timber operations. Additionally, they began to explore how their trees could provide additional benefits through carbon sequestration.

This re-examination led to an impetus to provide more sustainable livelihoods through diversified forest management within Southeast Alaska. Accordingly, the corporation has implemented a new sustainability strategy to better serve its rural shareholder communities, dedicated to revitalizing the regional economy by fostering "new and sustainable industries within rural communities" (Sealaska 2012). The corporation envisions four pillars of sustainability that contribute to its members' social and ecological well-being: (1) country or land-sea assets (Haa Aaní: Our Land); (2) ancestral heritage and destiny (Haa Shagóon: Our Past, Present, Future); (3) human development, through mental and physical strength and leadership (Haa Latseen: Our Strength, Our Leadership); and (4) the balance of humans in nature and society (Wooch. Yax, Balance, Reciprocity, Respect). Figure 1 shows how these pillars work together to balance ecosystem services with human needs and cultural services. As a model of a socialecological system, the schematic is akin to the generalized model found in the Millennium Ecosystem Assessment (2005), linking ecosystem services, i.e., supporting, provisioning, regulating, cultural, to specific constituents of well-being, security, material, health, social relations, and freedom. As such, it is a promising, though not yet fully implemented, model to guide Sealaska's emerging paradigm of corporate sustainability and social and environmental responsibility.

Among the most important spin-offs of Sealaska's reorientation toward social-ecological sustainability is the 2009 launch of a subsidiary named for one of the four assetvalue pillars: Haa Aaní, LLC. The new enterprise was conceived by the Sealaska Board of Directors as a means to create sustainable economies and communities in Southeast Alaska. The board was concerned that significant outmigration of villagers to urban centers as a result of the lack of employment could lead to the demise of Native villages (see Table 1). Thus Haa Aaní, LLC's mission became one of revitalizing "Southeast Alaska's rural communities ... suffering high unemployment rates, the loss of traditional jobs and a stagnant economy," and to reverse outmigration that "threatens the very fiber of rural community health and wellbeing" (Sealaska 2012). Given the realization that timber development alone from a village corporation land base of only 23,000 acres could not provide for sustainable development, key themes in the Haa Aaní strategic plans called for village "compatible lifestyle" or small scale investments in collaboration with village entities and other Native organizations. Initial investments have focused on oyster mariculture, fish processing, and the wood-pellet biomass energy initiative.

With soaring fossil fuel prices, development of a sustainable regional wood-biomass energy industry Haa Aaní, LLC became a strategic priority to stabilize the loss of population and investment in rural villages dependent on oil for heat and electricity (Table 1). According to Haa Aaní President and CEO, Russell Dick (personal communication 2012), up to $80 \%$ of a rural family's utility bill is oil-based heating costs. Initially, Haa Aaní considered several bioenergy alternatives, including ethanol, before focusing on wood-pellet production as the most viable. Haa Aaní helped Sealaska install a wood- 
Fig. 1. Sealaska Values in Action, a cultural model of sustainability and well-being, evolved partly as a result of the failure of first generation industrial logging on the limited corporation land base to produce sustainable benefits in Tlingit and Haida rural communities. Courtesy of Sealaska Corporation.
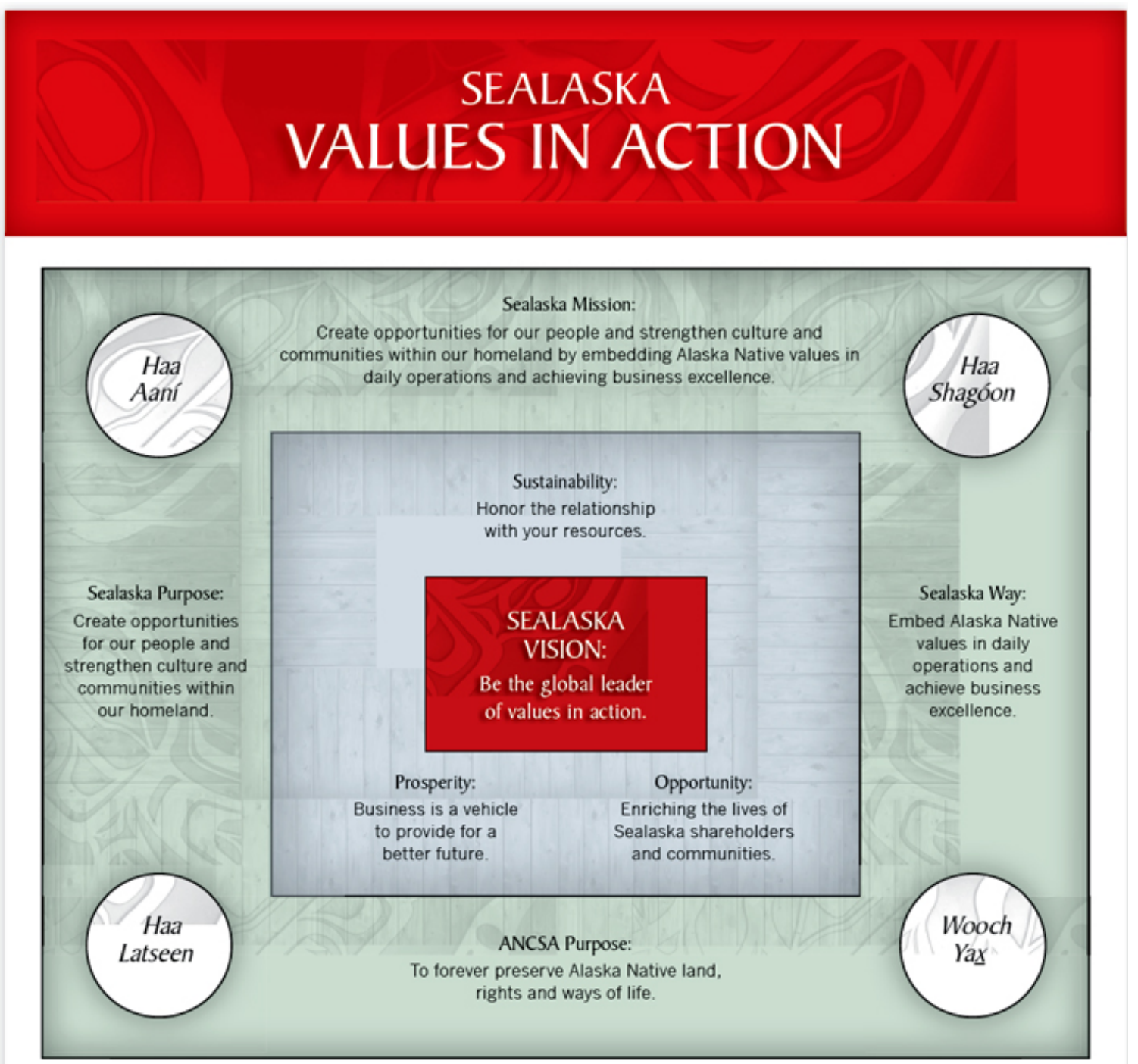

pellet based heating system in its Juneau corporate headquarters in 2010 as a first step toward demonstrating the benefits of biomass energy (Fig. 2). The company is now taking further steps to realize the benefits of switching to wood-pellet heating by promoting similar conversions in commercial and residential heating systems and capacity building among regional sawmills for wood-pellet production from local biomass residue. Mr. Dick notes that Haa Aaní is working with the Tlingit and Haida Regional Housing Authority, supported by a $\$ 500,000$ state grant to "a pilot conversion project in the community of Kake that will take 17 homes ... and convert them from heating oil to biofuel" (personal communication 2012). Similarly, Native villages currently dependent on expensive diesel power plants are considering wood-powered electrical generators to replace them, thus extending the benefits of biomass energy to electrification.

Despite these strategic opportunities and pilot conversions, however, practical barriers remain to a sustainable biomass industry that can bring net economic benefits to the region. At the same time there are environmental issues associated with biomass energy including air quality and greenhouse gas emissions, and compatibility with local cultural values and well-being. 
Table 1. Southeast Alaska Native village population trends in relation to urban centers, household income, energy sources, and unemployment.

\begin{tabular}{lcccc}
\hline \hline Community & $\begin{array}{c}\text { Population 2010 } \\
\text { \% change since 2000) }\end{array}$ & $\begin{array}{c}\text { HH Income 2009 } \\
(\% \text { change since 2000) }\end{array}$ & $\begin{array}{c}\text { Main Electricity } \\
\text { Source (Heat) }\end{array}$ & $\begin{array}{c}\% \text { Unemployment } \\
(\text { Poverty) }\end{array}$ \\
\hline Angoon & $459(-19.8 \%)$ & $\$ 25,753(-13.8 \%)$ & Diesel (oil) & $12.9 \%(28.6 \%)$ \\
Hydaburg & $376(-1.6 \%)$ & $\$ 35,651(12.7 \%)$ & Hydro with diesel (oil) & $31.3 \%(24.0 \%)$ \\
Hoonah & $760(-11.6 \%)$ & $\$ 52,360(34.2 \%)$ & Diesel (oil) & $20.6 \%(5.7 \%)$ \\
Kake & $557(-21.5 \%)$ & $\$ 36,163(-8.8 \%)$ & Diesel (oil) & $24.8 \%(18.1 \%)$ \\
Klawock & $755(-11.6 \%)$ & $\$ 44,024(25.8 \%))$ & Hydro with diesel (oil) & $15.6 \%(20.3 \%)$ \\
Klukwan & $95(-31.7)$ & $\$ 28,163(-8.3 \%)$ & Diesel (oil) & $44.8 \%(9.6 \%)$ \\
Saxman & $411(-4.6 \%)$ & $\$ 48,190(8.6 \%)$ & Hydro (oil) & $25.6 \%(15.5 \%)$ \\
Sitka & $8,881(+0.5 \%)$ & $\$ 61,007(17.5 \%)$ & Hydro (oil) & $7.8 \%(6.7 \%)$ \\
Wrangell & $2369(+2.6 \%)$ & $\$ 51,284(18.6 \%)$ & Hydro (oil) & $8.5 \%(9.8 \%)$ \\
Yakutat & $662(-2.6 \%)$ & $\$ 71,216(51.3 \%)$ & Diesel (oil) & $9.2 \%(3.4 \%)$ \\
Juneau $^{\dagger+}$ & $31,275(+1.8 \%)$ & $\$ 79,178(27.6 \%)$ & Hydro (oil) & $5.4 \%(6.7 \%)$ \\
\hline
\end{tabular}

${ }^{\dagger}$ Traditional village sites, now predominately non-Native

₹egional urban center

Sources: U.S. Census 2010; http://www.city-data.com

Fig. 2. Nathan Soboleff, a young Tlingit business leader, displaying Sealaska Corporation's wood-pellet based boiler, which has significantly lowered the firm's heating costs and carbon emissions.

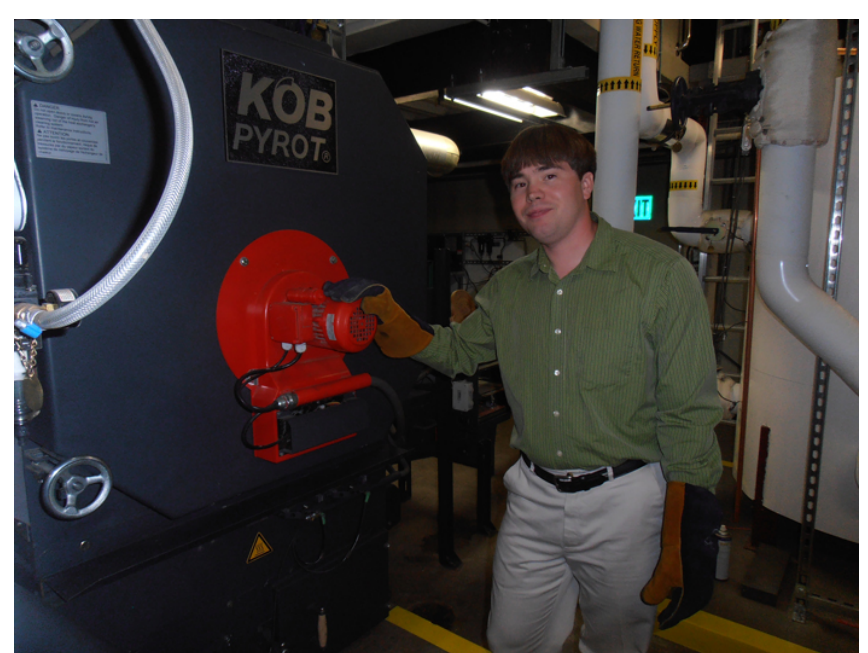

\section{ASSESSING SUSTAINABLE DEVELOPMENT}

One way of assessing sustainable development is through the triple bottom line (TBL) approach that focuses on three axes of sustainability: economic, social, and environmental (Elkington 1997, Petryni 2011). TBL is a popular framework to both conceptualize and assess corporate social responsibility. Under this approach, corporations that create environmental and social value alongside economic value are generally considered to have a sustainable bottom line. TBL can be an important tool to develop and support sustainability goals (WCED 1987) by focusing on the interrelated dimensions of profits (economic), people (social), and the planet (environment). Sealaska adopted this tripartite decision-making model, financial, environmental, and social license, to guide decisions on timber development activities.

In Southeast Alaska logging activity and employment in the forest sector have declined (Alexander et al. 2010). At the same time, the wood-waste or residue generated by the forest industry currently has no market and thus remains unclaimed. Potentially this logging by-product could be developed for biomass-energy generation. Transforming wood waste into energy, in turn, could create jobs, reduce adverse ecological impacts from unclaimed wood residue, e.g., fires, and introduce an alternative source of energy to burning costly oil for heating (N. Soboleff, personal communication 2011; Nash 2001). Moreover, wood-pellets displacing oil could help communities avoid large quantities of greenhouse gas emissions, thus reducing their carbon footprint. Thus, the TBL framework of sustainability highlights potential key economic, environmental, and social benefits of establishing a wood-biomass energy industry in the region.

\section{ENERGY ISSUES IN SOUTHEAST ALASKA}

As a temperate rainforest and marine archipelago, Southeast Alaska is a natural resource dependent economy with communities relying primarily on hunting, fishing, timber, mining, tourism, and government services for their livelihoods. The region is composed of communities with populations from as low as 50 and to over 30,000 in Juneau, the state capital. These communities draw their energy either from local hydro-power stations or fossil-fuels (oil/diesel-oil) imported by sea-routes. Although hydro is a major source of electricity in the region, most communities rely on oil for 
heating (Alexander et al. 2010). The high cost of fossil fuel in rural communities is a driver of outmigration and roadblock to investment and community sustainability in the region. As Alaska Senator Lisa Murkowski (2012) testified:

[I] t is hard for anyone to survive economically when they are paying $\$ 6$ to $\$ 11$ a gallon for heating oil and gasoline, and when electricity generated from diesel fuel reflects those sharp price hikes. High energy costs also affect everything from the price of airfare to villages to the cost of buying groceries, from the cost of running health clinics to the cost of preparing for subsistence hunts. As all commodities are flown into communities, the prices rural residents pay for the necessities of life are unjustifiably high. Every aspect of rural life has become a challenge with the high cost of fuel.

The cumulative impacts of oil energy costs have put many rural Southeast communities into what one elder terms "a death spiral” (Tlingit and Haida Regional Housing Authority 2011).

\section{WOOD-BIOMASS ENERGY}

Biomass is potentially an infinitely renewable resource comprising 4500 Exa Joules (EJ; $1 \mathrm{EJ}=1018$ Joules) of annual primary production. The annual biomass-energy potential is about 2900 EJ with approximately $1700 \mathrm{EJ}$ from forests and the remainder from grasslands and agricultural areas (Hall and Rao 1999, as cited in Rosillo-Calle et al. 2007). However, there are large variations in estimates of potential biomassenergy because of the complex nature of biomass production and use. Faaij et al. (2002, as cited in Rosillo-Calle et al. 2007) have estimated that 40 to $1100 \mathrm{EJ}$ energy could be generated from forestry and agricultural residues with no land available for energy farming. Industrial logging residues can amount to between $15 \%-40 \%$ of above ground volume, while sawn wood activity generates up to 50-67\% waste. Potentially, all of this waste can be used to produce energy, especially if the supplies are proximal and proportional to the demand (Rosillo-Calle et al. 2007).

Residues from forestry and agricultural activities are a large and currently underexploited energy resource, with vast potential for better utilization. A conservative estimate of the energy potential available from residues is about $70 \mathrm{EJ}$, including $36 \mathrm{EJ}$ from forestry residues alone (Rosillo-Calle et al. 2007). Macqueen and Korhaliller (2011) calculate that biomass energy makes up $10 \%$ of the total world primary energy mix, and $77 \%$ of the world primary renewable energy mix. Woody biomass accounts for $87 \%$ of annual biomass use globally. Moreover, biomass energy represents about 3\% of the primary energy mix in Organisation for Economic Cooperation and Development (OECD) countries and 22\% in non-OECD countries.

\section{BIOMASS POTENTIAL IN SOUTHEAST ALASKA}

Presently the residue generated from logging and saw-mill operations on some 400,000 acres of land within the Tongass National Forest has no market value and is thus left in situ. The material gradually decomposes and releases the stored carbon in the atmosphere (N. Soboleff, personal communication 2011; Nash 2001). Converting local forest residue to wood-pellets and burning these to provide heat energy could provide resource optimization and offers potential economic, environmental and social benefits to remote communities currently dependent on fossil-fuels.

Based on a conservative estimate, 174,400 tons per annum of wood-pellets could be sustainably produced from local biomass residue on Southeast Alaska's timber lands (Mater and Miles 2009). On the other hand, Brackley, et al. (2010) calculate the annual heating demand in the region to be approximately 268,000 tons of wood-pellets. Based on these supply and demand figures, it is evident that up to $65 \%$ of heating fuel demand could be met from local biomass residue.

Although the present study analyzes only biomass residue for making wood-pellets, the recent Southeast Alaska Integrated Resource Plan developed for Alaska Energy Authority (Black and Veatch 2011) estimates that $80 \%$ heating oil could be displaced with biomass energy in 10 years if young growth forest stands (40-50 years old) also were used for making pellets. The report further suggests that heating oil usage in the Southeast could be replaced entirely on less than 2000 acres of young growth per year. With a young growth timber base of approximately 500,000 acres in Southeast Alaska available for harvest, i.e., not restricted by conservation or other land uses, the harvest rate could be quite sustainable at less than $1 \%$ of the timber base per year.

Whether manufactured from residue or residue and young growth, wood pellets compare favorably to bioethanol or whole wood biomass energy in terms of cost and efficiency. The processing of material for ethanol was found to be too expensive (TSS Consultants 2000, Nash 2001) for small and medium-sized local corporations to support the capital costs, and wood logs too inefficient and logistically challenging because they require approximately 10 times the area of pellets for covered storage and drying (Brackley et al. 2010).

\section{TRIPLE BOTTOM LINE ANALYSIS}

\section{Economic benefits}

To estimate the economic benefit of biomass energy in Southeast Alaska, we compared the price per unit of energy paid by utilizing a particular fuel. This way the cost of energy is determined at various oil prices; and competitive woodpellets price is calculated to produce the same amount of energy (Fig. 3). 
Fig. 3. Oil-wood pellets price comparisons based on amount of energy produced.

\begin{tabular}{l|l}
\hline Oil (\$/gallon) & $\begin{array}{l}\text { Equivalent wood-pellet } \\
\text { price in \$/tonnes }\end{array}$ \\
\hline 4.50 & 518.40 \\
\hline 4.00 & 460.80 \\
\hline 3.50 & 403.20 \\
\hline 3.00 & 345.60 \\
\hline 2.00 & 230.40 \\
\hline
\end{tabular}

Derived from Brackley et al. (2010,p.19)

Green arrow: prevailing market price of wood-pellets

Red arrow: current market price of oil

Black arrow: price range at which operational savings could

be achieved by replacing oil-based heating with a pellet-

based system at its prevailing cost.

Currently, imported wood-pellets cost around \$300/ton and the current oil price is $\$ 4.17 /$ gallon in Southeast Alaska. The two fuels would be equal in cost if oil were priced at $\$ 3.00$ / gallon and wood-pellets priced at $\$ 345.60 /$ ton. Therefore, with current oil prices over $\$ 4.00 /$ gallon, huge operational savings could be achieved by switching to wood-pellets for heating. Although the cost of oil has risen precipitously over the past five years, the price for wood-pellets remains competitive, demonstrating a clear economic advantage for biomass energy over petroleum.

\section{Environmental benefits}

Emission factor values can be used to estimate avoided $\mathrm{CO}_{2}$ emissions by switching to pellet-based heating (Obernberger and Thek 2010) ${ }^{[1]}$. The total avoided emission by displacing oil with wood-pellets is calculated for a potential supply capacity of 174,400 tons of pellets (Box 1). This shows a clear advantage in terms of reduced emissions and resulting climate protection. Therefore, along with the economic advantage, an inherent advantage in the form of $\mathrm{CO}_{2}$ reduction could be realized and promoted as a cobenefit of using wood-pellets over oil for heating. Air quality is another concern. Current pellet-based systems yield emissions of $\mathrm{CO}$ (carbon monoxide), NOx (nitrous oxide), SOx (sulphur oxide), and PM (particulate matter), the latter two in greater quantity when compared with oil-based heating (Helle et al. 2009). This is not a trivial issue because occasional atmospheric conditions in valley environments can lead to the unhealthy build-up of smoke and particulate pollution from wood-fuel combustion exhaust, particularly when these heating units are concentrated in urban areas. However, the research on which of these values are determined (Obernberger and Thek 2010) also states that emissions could be further reduced through incorporation of new technological developments. Therefore it can be said that the emission factor values from wood pellets in Box 1, in the case of both noxious gases and particulate dust, are conservatively overvalued with respect to future deployment of up-to-date pellet-based systems. Indeed wood pellet boilers already have achieved major gains in efficiency and interior and exterior air pollution reduction over traditional wood stoves. Solid waste ash produced by wood-pellet combustion must also be considered because it would require landfill space, unless converted to other uses such as fill or soil enhancement (Helle et al. 2009).

Box 1: Total Emission Savings in tonnes-achieved by consuming 174,400 tons pellets and displacing oil.

$\mathrm{CO}_{2}$

Wood-Pellets 12590.28

Oil 276986.25

Emission avoided 264395.96 (tonnes)

Carbon Monoxide

Wood-Pellets 388.82

Oil 152.91

Emission avoided -235.91 (tonnes)

$\mathrm{C}_{\mathrm{x}} \mathrm{H}_{\mathrm{y}}$

Wood-Pellets 72.60

Oil 169.01

Emission avoided 96.41 (tonnes)

NOx

Wood-Pellets 443.32

Oil 313.88

Emission avoided -129.44 (tonnes)

$\mathrm{SO}_{2}$

Wood-Pellets 53.15

Oil 250.50

Emission avoided 197.35 (tonnes)

Dust

Wood-Pellets 93.73

Oil 18.78

Emission avoided $\mathbf{- 7 4 . 9 5}$ (tonnes)

Note: The Emission Factor (EF) values are in mg/MJ (milligrams per Mega-Joule of Energy, adapted from Obernberger and Thek 2010).

Wood-pellets sold in tons (a metric quantity) in the market, when displacing oil, can lead to reduced emissions of greenhouse gases (measured in tonnes in international markets). To facilitate the calculation we provide a direct formula based on quantity of pellets used (in tons) and yielding and estimate of gas emissions reduced (avoided - in tonnes).

The formula generated for this conversion is:

Emission (tonnes) $=$ Quantity of Fuel (oil/wood-pellets) in Tons * $19.23 * 10^{-6} * \mathrm{EF}$ of gas.

This formula could be used to conservatively calculate environmental benefits of promoting wood-pellets over oil in other regions of Alaska and beyond. 


\section{Social benefits}

Unlike the economic and environmental benefits, the social benefits associated with regional biomass-energy industry are more speculative because of the absence of a mature biomassenergy industry in the region. However, the most readily apparent social benefit to those dwelling in Alaska Native communities is that use of wood pellets over oil can affirm their core asset-values of Haa Aaní and Haa Shagóon, utilizing the land while protecting their resources and heritage for future generations. Moreover, Sealaska is assessing how development of a biomass industry might be implemented to diminish the adverse effects of climate change.

Employment generation is also a major social benefit associated with the regional wood-pellet industry. Russell Dick, CEO of Haa Aaní, LLC, believes his company can profitably import wood-pellets from the greater Alaska bioregion and distribute them to retail outlets, employing a modest workforce to manage this regional enterprise. The company's ultimate aims are more ambitious, however. As a Native corporation, Sealaska envisions leveraging its resources and business objectives to develop a wood-pellet production facility and supply chain using local biomass residue within Southeast Alaska thereby creating a greater societal benefit of Native shareholder employment in a regional biomass-energy industry. However, this broader aim will require significant long-term investment and policy support.

Reduced energy costs associated with biomass could further stimulate business development and jobs in the villages and enable villagers to remain in their communities rather than migrating to urban centers with cheaper energy, like Anchorage and Juneau. The pilot experiment in Kake to convert 17 households from oil to wood-pellet heat may help stem outmigration and disinvestment in a community that has lost $21.5 \%$ of its population since 2000 . In the meantime, switching to wood-pellets holds the immediate social benefit of reducing community dependence on oil and vulnerability to its volatile prices and environmental risks.

Although it is not clear just how many gainful jobs could be supported in the long-term by a regional wood biomass energy industry, these jobs would complement rather than displace existing jobs in the forestry sector because residue is associated with ongoing timber operations. At the same time, removal of forest waste has the potential to increase access to the forest for those seeking subsistence and nontimber forest resources, which might otherwise be inaccessible because of the buildup of timber residue in the forest understory. Other cultural values, such as subsistence uses of the forest, heritage sites, and culturally modified trees, could be protected according to standard environmental assessments and existing provisions under ANCSA. Thus, it appears that there could be significant positive net environmental, economic, and sociocultural benefit from a regional biomass energy industry without significant adverse impacts on key cultural resources.

\section{GLOBAL CLIMATE CHANGE MITIGATION AND TONGASS NATIONAL FOREST}

Around the world, forests are seen as carbon sinks to mitigate climate change. On the other hand, burning wood-biomass for energy releases stored carbon into the atmosphere. Thus, it is important to consider climate change related impacts of promoting wood-biomass energy. With respect to the benefits of sustainably managing forests for carbon mitigation, the Intergovernmental Panel on Climate Change (IPCC 2007) has concluded, "In the long term, a sustainable forest management strategy aimed at maintaining or increasing forest carbon stocks, while producing an annual sustained yield of timber, fiber, or energy from the forest, will generate the largest sustained mitigation benefit."

The life cycle carbon accounting approach can be used to compare emission impacts of fossil-fuel and biomass energy. Using this approach Lippke et al. (2011) find that, although forests are carbon sinks (storage pools), when biomass is burned as a fuel, the fossil-fuel emissions are displaced. While fossil-fuel emissions flow one way from deep reserves to the atmosphere, carbon emitted by burning biomass could be absorbed by regenerating forests, thereby making it a renewable energy source. By sustainably harvesting, i.e., not removing more biomass than is grown on a forest landscape, the forest carbon emission-to-sequestration ratio does not change. Moreover, this forest carbon neutrality is not limited to a regulated, even-aged forest but applies to multistoried forests and use of selective cutting methodologies too.

Thus, although burning of biomass is not carbon neutral, if sourced in a manner that does not lead to depletion of the forest base, the biomass is replaced and remains a renewable resource. As Daniel Parrent (as cited in Condra 2012), Biomass and Forest Stewardship Coordinator for the U.S. Forest Service, reasons: "when you consider that you're not precluding forest regrowth — that ...those new trees recapture the carbon that was emitted from the trees you burned ...yes there is a small price to pay for harvesting and processing and transportation, but biomass energy is about 95 percent carbon neutral." In contrast, if saw-mill and logging residue lays unutilized as waste, eventually it decays, emitting $\mathrm{CO}_{2}$ in the process. Using forest residues to displace oil for heating avoids this waste factor while also significantly reducing GHG emissions through avoided burning of fossil-fuels (JEDC 2011a; N. Soboleff, personal communication 2011).

When balanced with prudent forest management to conserve key ecosystem and cultural services, such as carbon sequestration, biodiversity, and subsistence land uses, sustainable wood biomass energy can be an efficacious strategy for climate-compatible development in northern forest communities. By reducing dependence on nonlocal oil 
supplies, and localizing energy needs in a sustainable local forest economy, rural communities can bolster their resilience to energy supply and price shocks, while at the same time reducing their carbon footprint and developing more sustainable livelihoods.

\section{THE FUTURE OF BIOMASS ENERGY: LINKING THE LOCAL AND GLOBAL}

The capacity to sustainably harvest local biomass and the economic incentive for the users to switch are important factors in wood-pellets displacing oil in Southeast Alaska. However, there are critical ecological, economic, and political constraints that need to be overcome for a sustainable woodpellet industry to develop, both locally and globally.

\section{Ecological constraints}

Globally the large scale utilization of biomass-energy poses potential environmental impacts. These include: (1) possible destruction of forests due to increasing commercial applications of biomass-energy, such as for electricity generation; (2) degradation of soils, nutrient cycles, and other ecosystem services by continuous removal of residues for energy; and (3) adverse impacts of transporting large quantities of biomass, e.g., increased road construction, traffic, and emissions (Rosillo-Calle et al. 2007). For a wood-pellet industry in Southeast Alaska, residue from saw-mill and logging operations constitutes the major raw-material, rather than conversion of standing trees; hence these potential impacts do not appear to pose a significant threat in the current design. However, along with air pollution levels from wood combustion, these impacts would have to be monitored and potentially regulated to avoid adverse effects on human populations and ecosystems.

\section{Supply constraints}

Logging activity has declined in the region over last two decades and operational and legal costs, associated with litigation by opposition groups, of industrial timber harvest in the region have risen (Alexander et al. 2010; N. Soboleff, personal communication 2011). Under the uncertain future of forest industry, a secure supply of raw material is considered a major barrier for a stable, regional wood-pellet industry to develop (A. Brackley, personal communication 2011). This constraint may be mitigated by surplus biomass supplies in the greater Pacific Northwest bioregion, which supports large forests and a significant timber industry.

\section{Demand constraints}

Despite the clear benefits of using wood-pellets over oil, adoption of the technology by the end users depends on several other key factors. These include replacement costs of heating equipment, environmental regulations and incentives to switch, ease of use, and fuel storage. Therefore, conversion among the various sources of energy, especially woodbiomass, is complex and fuel-price itself may not be the only pivotal factor (Brackley et al. 2010).

\section{High production costs}

Local producers may have a competitive transportation advantage when serving local markets owing to lower transportation costs than those faced by a nonlocal competitor. However, it is not uncommon for this competitive advantage in local transportation costs to be offset by higher production costs in Alaska's remote setting (Brackley et al. 2010). At the same time transport companies today must charge "either significantly higher rates in these [remote rural] communities [because of costs] or just start pulling back [on frequency of service]" (R. Dick, personal communication 2012). Haa Aaní, LLC is examining investments in the transportation sector within the region as an opportunity to address these higher logistical costs and the complex supply chain management issues for rural residents and markets. Its entry into the transportation sector could conceivably offset the higher biomass production and distribution costs throughout the region.

\section{THE ROLE OF ENERGY POLICY MEASURES: LESSONS FROM EUROPE}

The above constraints suggest that development of a sustainable wood-biomass industry in Southeast Alaska will require policy support measures. Although Sealaska holds title to several hundred thousand acres of forest land, and manages a significant portion its forests for commercial timber, it is currently not economically feasible for the company to capitalize on timber residues for biomass energy. Moreover, despite some state capital, the cost and other barriers to adoption of wood-pellet conversions remain significant. New technologies, market development, and institutional partnerships are needed. Sealaska leaders believe that favorable policies, such as tax on fossil-fuel carbon emissions (R. Harris, personal communication 2011), could play a pivotal role in the adoption of wood-pellets for energy in the region. Other measures to facilitate transition from fossil fuels to biomass may include investment subsidies for replacement of heating equipment, feed-in-tariffs for renewable energies, and tighter environmental regulations at the community, state, and federal levels.

In Europe such policy measures have proven to be an important driver for increasing wood-pellet demand (Obernberger and Thek 2010). In the Netherlands, for example, a system of feedin premiums (tariffs) for renewable electricity has made the cofiring of clean woody biomass with coal an economically attractive alternative. In Belgium a quota system of green certificates was introduced requiring suppliers of electricity to reach a certain share of renewable electricity. This has led to the conversion of coal power plants to wood pellets. Sweden imposed a tax on fossil-fuel use for heating that has led to continuously increasing use of wood-pellets for district heating and Combined Heat and Power (CHP) production. The majority of pellets are produced domestically but with increasing demand, imports of wood-pellets have been 
growing recently. Finally, in Finland a series of initiatives, including a $\mathrm{CO}_{2}$ tax, investment subsidies, and research and development investment have contributed to the large-scale adoption of wood-pellets (Nicholls et al. 2009).

Beyond policy support tools for conversion, the northern European experience also reveals key social-ecological conditions requisite for a sustainable biomass industry. These include: (1) large forestry operations and the potential of using biomass for meeting energy needs; (2) low population densities with little conflicting use of forest lands; and (3) a large forest base capable of meeting biomass requirements on a sustainable basis without harm to ecosystem services or major importation beyond the bioregion, an issue in Europe. These conditions exist in Alaska and may also hold for remote forested regions in Canada, Russia, and elsewhere (Nicholls et al. 2009).

\section{Investment subsidies}

High initial investment costs are a major barrier to pellet-based heating systems. For example the total cost of boiler installation in Sealaska's 58,000 square foot four-story corporate headquarters amounted to approximately $\$ 539,000$ (N. Soboleff, personal communication 2011). Although significant operational savings are projected throughout the life cycle of this system, the initial, one-time investment is quite high and may discourage other users in the region, despite rising oil prices. Therefore, investment grants or technology transfer tax credits, low-interest, loans, or subsidies could be an effective policy approaches to promote adoption of pelletbased heating systems (JEDC 2011b). Currently, the State of Alaska's renewable energy fund helps with costs for larger facilities, and the U.S. Department of Agriculture Rural Development and Department of Energy programs also provide support for renewable energy projects. Sealaska was assisted by the federal government's Denali Commissions' Emerging Energy Technology funds. Energy transition policies, like those adopted by Finland and other European countries to promote the use of biomass over fossil-fuels, could significantly reduce present constraints hindering development in this sector. Carbon taxes, investment subsidies and feed-in tariffs are proven policy instruments that could facilitate quick adoption of wood-pellets and address regional energy security and community vulnerability while at the same time yielding demonstrable environmental benefits by displacing oil.

\section{RECOMMENDATIONS}

The benefits of a sustainable wood-biomass industry are clear, and adequate, sustainable supplies of biomass are available in Southeast Alaska to effectively displace oil as heating fuel while creating potential economic and sociocultural benefits. However, effective and sustainable development of the industry in Alaska and elsewhere will require indigenous and nonindigenous investors alike to consider:
1. What potential do local sources of biomass have to meet energy needs? In Southeast Alaska, forest residue can meet up to $65 \%$ of heating energy demand. A local, renewable energy source of this magnitude can deliver real, sustainable economic, environmental, and social benefits.

2. How will development of a wood-biomass energy sector affect the forest ecosystem? Policy makers need to consider not only the supply of wood residue but how it is accessed, transported, processed, and utilized by other species, all of which impact on the ecosystem.

3. What are the key economic thresholds for transition to biofuels? The formulae used in this study can be applied to calculate environmental benefits of wood-pellets over oil in any region, according to local price configurations.

4. What kind of public-private partnerships and policies are needed to promote the transition to sustainable biomass energy? Biomass processing facilities and installations of wood-pellet heating systems require high capital investment. Supportive policies and cofinancing to help underwrite transition costs can be critical in facilitating the move to biomass energy.

5. What is needed to build community support for biomass energy? Alaska Native corporations in the Tongass National Forest are important catalysts in the transition to biomass energy because they have recognized energy security as a key vulnerability in their communities. In addition, they possess strong networked constituencies, clear land rights, and significant natural, financial, and human capital to support a new energy infrastructure, which other rural indigenous and forest communities may lack. The catalytic potential of Alaska Native corporations is further strengthened through realization of their core values of sustainability, which are increasingly being articulated as a basis for future business plans.

A recent letter from the Tlingit CEO of Yak-tat Kwaan Inc., (YTK, Yakutat Native village corporation), which has followed Sealaska into biomass energy, sums up the potential and challenges, i.e. investment capital, if these key issues are addressed:

Everybody understands the high costs of living in Yakutat. Our Biomass project represents an exciting opportunity to address our high costs of energy head-on. ... [T]hrough effective use of biomass resources we will reduce our dependence on fossil fuel, improve our land, protect our environment and stimulate our local economy. YTK is taking the lead in the development of renewable energy sources and creating the innovate paths of emerging electrical/ heat generation. In synchronization with the city, 
tribe and the forest service, YKT is leading a biomass project. Although still in its infancy, we have reached major benchmarks in definition and are out fundraising for further development (Bremner 2011).

Other developing countries and proponents of sustainable development according to local ecosystem services can learn from Haa Aaní, LLC's and Yak-tat Kwaan, Inc.'s experiences in attempting to develop a sustainable energy source based on their forest assets and a triple bottom line of benefits in accordance with their cultural model of sustainability and well-being.

\section{CONCLUSION}

To address the increasing energy vulnerabilities of remote northern communities dependent on fossil fuels, we have assessed the costs and benefits of potential wood-biomass energy development in Southeast Alaska, and the unique role that indigenous corporations and their emerging models of sustainability and social-ecological well-being have played in advancing the biomass energy transition. A triple bottom line sustainability analysis of regional wood-pellet industry shows its potential for increasing economic, environmental, and social benefits to rural Southeast Alaska. Finally, the study pinpoints key constraints that a biomass energy industry is likely to face and policy support measures that have been implemented in other countries that could benefit a regional wood-pellet industry in the Pacific Northwest.

However, development of a wood biomass industry is not without risks and environmental impacts. Ecological impacts can be significant if biomass production comes at the expense of other ecosystem services and human needs, such as subsistence hunting, fishing, and gathering. It is also necessary to provide enough sustainable biomass to create secure economies of scale for the production and distribution of biomass fuels in the region (Benjamin 2010). In contrast to palm oil plantations and other controversial models of forest conversion for biofuel development, the Alaska model does not require expansion or conversion of existing timber lands to meet projected demand for wood-pellets. Rather it takes advantage of the currently untapped resource of wood waste from ongoing timber operations. Our results suggest biomass energy could develop in Southeast Alaska through the strategic and efficient capture of wood waste with minimal environmental impacts as compared to reliance on fossil fuels for heating or alternative biofuel options, such as ethanol or wood chips. Approximately 265,000 tonnes of $\mathrm{CO}^{2}$ emissions would be avoided annually by consuming 174,400 tons of wood-pellets and replacing oil for heating in Southeast Alaska, a significant climate benefit.

The 1971 Alaska Native Claims Settlement Act provided opportunities for economic and social development of Alaska Natives by securing within newfound Native corporations title to a portion of Natives' traditional lands and financial resources (compensation for lands taken) for investment in their futures. In Sealaska's case, after experimenting with industrial logging that has not proven sustainable, the corporation is actively reorienting its operations to support alternative energy and sustainable livelihoods, potentially with wood residue from its own timber operations, along with sustainable timber harvests and monetization of its forest ecosystem and cultural services. To remain sustainably rooted in the Tongass, the corporation has already spent nearly $\$ 20$ million on scientific research and stewardship planning to overcome the limitations of its fragmented land base under ANCSA. Other rural indigenous corporations, such as YakTat Kwaan, Inc. are beginning to follow suit. If successful, their model could be one for indigenous and rural forest peoples elsewhere to emulate and adapt through development under Reduced Emissions from Deforestation and Forest Degradation (REDD+) and other schemes in which indigenous land tenure, subsistence and sustainable development needs, and roles in forest governance are yet to be fully addressed (Poffenberger and Smith-Hanssen 2009).

${ }^{[1]}$ The quantity of various gases emitted by burning woodpellets and oil for centralized heating systems are calculated by Obernberger and Thek (2010). These values are based on the Austrian framework conditions concerning fuel supply, distribution, and utilization. Therefore, minor differences are expected in these values in a different country because of possible differences in energy consumption during the production of fuels. However, this is presumed to have minimal absolute influence and has been ignored in the calculations.

Responses to this article can be read online at: http://www.ecologyandsociety.org/issues/responses. $\mathrm{php} / 5763$

\section{Acknowledgments:}

The authors gratefully acknowledge Nathan Soboleff, Russell Dick, Trista Patterson, Allen Brackley, and the Climate and Development Knowledge Network (CDKN), National Science Foundation (NSF), and St. Anne's College, University of Oxford for their support.

\section{LITERATURE CITED}

Alexander, S. J., E. B. Henderson, and R. Coleman. 2010. Economic analysis of Southeast Alaska: envisioning a sustainable economy with thriving communities. Publication R10-MB-725. Forest Service, Alaska Region, Juneau, Alaska, USA. 
Benjamin, J. G., editor. 2010. Considerations and recommendations for retaining woody biomass on timber harvest sites in Maine. Miscellaneous Publication 761. University of Maine, Maine Agricultural and Forest Experiment Station, Orono, Maine, USA.

Berger, T. 1985. Village journey. Hill \& Wang, New York, New York, USA.

Berkes, F. 2008. Sacred ecology. Second Edition. Taylor and Francis, Philadelphia, Pennsylvania, USA.

Black and Veatch. 2011. Southeast Alaska integrated resource plan. Alaska Energy Authority, Anchorage, Alaska, USA. [online] URL: http://www.akenergyauthority.org/seirp-comments. $\underline{\mathrm{html}}$

Brackley, A. M., V. Barber, and C. Pinkel. 2010. Developing estimates of potential demand for renewable wood energy products in Alaska. General Technical Report PNWGTR-827. U.S. Forest Service, Pacific Northwest Research Station, Portland, Oregon, USA.

Bremner, C. 2011. Yak-Tat Kwaan, Inc. News, 3(1):1.

Condra, Amy. 2012. Southeast energy challenges lead to interest in biomass: increasing diesel costs, shortage of hydro storage lead to talk of shift toward biomass to ease Southeast Alaska's energy demand. Juneau Empire, 27 January. [online] URL: http://juneauempire.com/outdoors/2012-01-27/southeastenergy-challenges-lead-interest-biomass\#.UkBjAD-TXpc

Dombrowski, K. 2002. The praxis of indigenism and Alaska Native timber politics. American Anthropologist 104 (4):1062-1073. http://dx.doi.org/10.1525/aa.2002.104.4.1062

Durbin, K. 2005. Tongass: pulp politics and the fight for the Alaska Rain Forest. Second Edition. Oregon State University Press, Corvallis, Oregon, USA.

Elkington J. 1997. Cannibals with forks: the triple bottom line of 21 st century business. Capstone, Oxford, UK.

Emmons, G. T., and F. de Laguna. 1991. The Tlingit Indians. Edited with additions by Frederica de Laguna. American Museum of Natural History Anthropological Papers, vol. 70. University of Washington Press, Seattle, Washington, USA.

German, L., G. C. Schoneveld, and P. Pacheco. 2011. The social and environmental impacts of biofuel feedstock cultivation: evidence from multi-site research in the forest frontier. Ecology and Society 16(3): 24. http://dx.doi. org/10.5751/ES-04309-160324

Helle, S., A. Fredeen, M. Rutherford, G. Halseth, M. Gillingham, K. Parker, and H. Massicotte. 2009. Biomass energy in central British Columbia: framing the issues. Occasional Paper Series, No. 4, January. University of Northern British Columbia, Natural Resources and
Environmental Studies Institute, Prince George, British Columbia, Canada.

Hunn, E. S., D. R. Johnson, P. N. Russell, and T. F. Thornton. 2003. Huna Tlingit traditional environmental knowledge and conservation of a "wilderness" park. Current Anthropology 44:S79-S103. http://dx.doi.org/10.1086/377666

Intergovernmental Panel on Climate Change (IPCC). 2007. Climate change 2007: mitigation of climate change. B. Metz, O. R. Davidson, P. R. Bosch, R. Dave, L. A. Meyer, editors. Contribution of Working Group III to the Fourth Assessment Report of the IPCC. Cambridge, University Press, Cambridge, UK.. http://dx.doi.org/10.1017/CBO9780511546013

Juneau Economic Development Council (JEDC). $2011 a$. Southeast Alaska action initiatives for key economic clusters. JEDC, Juneau, Alaska, USA.

Juneau Economic Development Council (JEDC). $2011 b$. Meeting summary. Southeast Alaska Renewable Energy-Seed Cluster Working Group Meeting 1. JEDC, Juneau, Alaska, USA.

Lippke, B., E. Oneil, R. Harrison, K. Skog, L. Gustavsson, and R. Sathre. 2011. Life cycle impacts of forest management and wood utilization on carbon mitigation: knowns and unknowns. Carbon Management 2:303-333. http://dx.doi. org/10.4155/cmt.11.24

Macqueen, D., and S. Korhaliller. 2011. Bundles of energy: the case for renewable biomass energy. Natural Resource Issues No. 24. International Institute for Environment and Development, London, UK.

Mater, C. M., and T. Miles. 2009. Feasibility assessment of producing a wood waste alternative fuel product on Prince of Wales Island. Mater Ltd., Corvallis, Oregon, USA.

Millennium Ecosystem Assessment. 2005. Ecosystems and human well-being: synthesis report. Island Press, Washington, D.C., USA.

Murkowski, L. 2012. Alaska Natives and rural Alaska. [online] URL: http://www.murkowski.senate.gov/public/ index.cfm?p=Energy

Nader, L., editor. 2010. The energy reader. Wiley-Blackwell, Oxford, UK.

Nash, C. E. 2001. Analysis of woodfiber feedstick availability for a proposed ethanol plant in Southeast Alaska. National Renewable Energy Laboratory, Denver, Colorado, USA.

Natcher, D. G., C. G. Hickey, M. Nelson, and S. Davis. 2009. Implications of tenure insecurity for Aboriginal land use in Canada. Human Organization 68(3):245-257.

Nicholls, D., R. A. Monserud, and D. P. Dykstra. 2009. International bioenergy synthesis-Lessons learned and 
opportunities for the western United States. Forest Ecology and Management 257:1647-1655. http://dx.doi.org/10.1016/ j.foreco.2008.11.035

Obernberger, I., and G. Thek. 2010. The pellet handbook: the production and thermal utilisation of pellets. Earthscan, London, UK.

Ostrom, E. 2009. A general framework for analyzing sustainability of social-ecological systems. Science 325:419-422. http://dx.doi.org/10.1126/science.1172133

Petryni, M. 2011. Definition of triple bottom line sustainability. eHow. [online] URL: http://www.ehow.co.uk/ about 6547401 definition-triple-bottom-line-sustainability.html

Poffenberger, M., and K. Smith-Hanssen. 2009. Forest communities and REDD climate initiatives. Asia Pacific Issues (East West Center) Issue No. 91. Honolulu, Hawaii, USA.

Rosillo-Calle, F., S. Hemstock, P. de Groot, and J. Woods, editors. 2007. The biomass assessment handbook: bioenergy for a sustainable environment. Earthscan, London, UK.

Sealaska. 2012. Haa Aaní, LLC. Sealaska Corporation, Juneau, Alaska, USA. [online] URL: http://www.sealaska. com/page/haa-aani-1lc.html

Smith, E. A., and M. Wishnie. 2000. Conservation and subsistence in small-scale societies. Annual Review of Anthropology 29:493-524. http://dx.doi.org/10.1146/annurev. anthro.29.1.493

Survival International. 2008. Biofuels threaten lands of 60 million tribal people. Survival International, London, UK. [online] URL: http://www.survivalinternational.org/news/3279

Thornton, T. F. 2002. From clan to Kwaan to corporation: the continuing complex evolution of Tlingit political organization. Wicazo Sa Review 17(2):167-194. http://dx.doi. org/10.1353/wic.2002.0022

Thornton, T. F. 2007. Alaska Native corporations and subsistence: paradoxical forces in the making of sustainable communities. Pages 41-62 in C. A. Maida, editor. Sustainability and communities of place. Berghahn Books, New York, New York, USA.

Thornton, T. F., and H. Kitka, Sr. 2010. The Tlingit way of conservation: a matter of respect. Pages 211-218 in K. Walker Painemilla, A. B. Rylands, A. Woofter, and C. Hughes, editors. Indigenous peoples and conservation: from rights to resource management. Conservation International, Arlington, Virginia, USA.

Tlingit and Haida Regional Housing Authority. 2011. Central Council of the Tlingit and Haida Indian Tribes of Alaska: Tlingit and Haida Regional Housing Authority - 2011 Project.
Tribal Energy Program, U.S. Department of Energy, Washington, D.C., USA. [online] URL: http://apps1.eere. energy.gov/tribalenergy/projects detail.cfm/project id=193

TSS Consultants. 2000. Southeast Alaska biomass-to-ethanol project feedstock supply plan. TSS Consultants, Rancho Cordova, California, USA.

U.S. Census Bureau. 2010. 2010 Census Data. U.S. Census Bureau, Washington, D.C., USA. [online] URL: http://www. census.gov/2010census/data/

World Commission on Environment and Development (WCED). 1987. Our common future. Oxford University Press, Oxford, UK. 